\title{
PENGUATAN KUALITAS DAN KREATIFITAS GURU MELALUI CARTOON STORY MAKER
}

\author{
Rini Fadhillah Putri ${ }^{1)}$, Rizqy Fadhlina Putri ${ }^{2)}$ \\ Universitas Muslim Nusantara Al Washliyah ${ }^{1)}$ \\ Universitas Muslim Nusantara Al Washliyah ${ }^{2)}$ \\ rinifadhillah@umnaw.ac.id \\ rizqyfadhlina@umnaw.ac.id
}

\begin{abstract}
ABSTRAK
Sekolah Dasar Swasta Islam Uli Arga yang terletak di Kecamatan Patumbak, Kabupaten Deli Serdang adalah mitra pengabdian ini. Belum maksimalnya penggunaan media digital di sekolah ini membuat pembelajaran menjadi monoton, padahal di era saat ini, pembelajaran berbasis teknologi sangat dibutuhkan. Oleh karena itu, pembelajaran dengan menggunakan media digital harus mulai dilakukan. Salah satu medianya adalah cartoon story maker. Cartoon story maker dapat digunakan untuk membuat kartun 2(dua) dimensi yang menggambarkan percakapan atau dialog dengan cara yang menarik. Software ini dilengkapi dengan berbagai karakter dengan ekspresi wajah yang berbeda-beda serta latar cerita yang beragam, bisa juga menggunakan gambar sendiri. Dengan menggunakan media ini, pembelajaran akan menjadi aktif dan menyenangkan.
\end{abstract}

Kata kunci : Media Digital, Cartoon Story Maker.

\section{ABSTRACT}

Uli Arga Islamic Private Elementary School located in Patumbak District, Deli Serdang Regency is this dedication partner. The minimum use of digital media in this school makes learning monotonous, whereas in the current era, technology-based learning is needed. Therefore, learning using digital media must be started. One of the media is cartoon story maker. Cartoon story maker can be used to create 2 (two) dimensional cartoons that describe a conversation or dialogue in an interesting way. This software is equipped with various characters with different facial expressions and diverse story settings, can also use their own images. By using this media, learning will become active and enjoyable.

Keywords : Digital media, Cartoon Story Maker

\section{PENDAHULUAN}

Sekolah Dasar Swasta Islam Terpadu Uli Arga yang berlokasi di Jalan Mambang Diawan V Patumbak Sigara-gara Kecamatan Patumbak Kabupaten Deli Serdang adalah mitra pengabdian masyrakat yang merupakan mitra kerjasama yang berkesinambungan. Lokasi ini berjarak sekitar $7,7 \mathrm{~km}$ dari Universitas Muslim Nusantara (UMN) AlWashliyah dengan kendaraan bermotor.

Hasil observasi di SD Swasta dan wawancara dengan guru-guru menyatakan bahwa belum maksimalnya penggunaan media digital seperti cartoon story maker. Media ini belum pernah digunakan sebagai media pembelajaran. Hal ini dikarenakan guru sudah terbiasa dengan pengajaran dan penggunaan media konvensional.

Kondisi ini dipertegas oleh gambar sistem pembelajaran di kelas di SD Swasta Islam Terpadu Uli Arga Kecamatan Patumbak Kabupaten Deli Serdang.

Dari gambar di atas dapat dilihat bahwa guru masih menggunakan metode yang biasa dan minimnya penggunaan media dalam pembelajaran.

Padahal, perkembangan teknologi berpengaruh terhadap pendidikan. Dimana pada dasarnya pendidikan merupakan suatu proses komunikasi dan informasi dari 
pendidik kepada peserta didik yang berisi informasi-informasi pendidikan, yang memiliki unsurunsur pendidik sebagai sumber informasi, media sebagai sarana penyajian ide, gagasan dan materi pendidikan serta peserta didik itu sendiri. Dengan kemajuan teknologi saat ini, guru harus mampu memanfaatkan teknologi dan mengelaborasi kreativitasnya dalam pengajaran agar anak dapat dididik sesuai dengan jamannya. Hal ini juga dapat menjadi catatan untuk para guru untuk merubah cara pandang mereka dan segera memanfaatkan teknologi baru untuk membantu mereka menyampaikan materi dengan lebih efektif. Kini sudah saatnya guru memanfaatkan teknologi yang tepat demi pendidikan yang lebih maju.Teknologi ini juga dapat menciptakan suasana pembelajaran yang aktif dan interaktif, sehingga guru dapat meningkatkan kualitas pembelajaran dan dengan leluasa menggunakan kreativitasnya dalam penggunaan media digital. Media pembelajaran berbasis teknologi juga dapat membuat pembelajaran lebih powerfull dimana kontak komnunikasi antara individu yang ditunjang oleh teknologi dapat memberi nilai tambah dalam komunikasi tertentu. Pemanfaatan media baru dalam berbagai aspek, khususnya aspek pendidikan harus diberdayakan oleh berbagai unsur pendidikan. Salah satunya adalah siswa. Mereka harus mampu memaksimalkan media baru dalam memenuhi perannya sebagai makhluk pembelajar dan makhluk sosial. Siswa harus memanfaatkan media baru dalam proses pembelajaran, terutama terhadap komponen proses belajar mengajar, yakni untuk mencapai tujuan pembelajaran, sumber belajar, bahan belajar, alat pembelajaran (media) dan dalam proses penilaian. Menurut Arsyad dalam Firdaus mengemukakan bahwa pemakaian media pembelajaran dalam proses belajar mengajar dapat membangkitkan keinginan dan minat baru, membangkitkan motivasi dan merangsang kegiatan belajar, dan bahkan membawa pengaruhpengaruh psikologi terhadap siswa. Penggunaan media pembelajaran pada tahap orentasi pembelajaran akan sangat membantu keefektifan proses pembelajaran dan penyampaian pesan dan isi pembelajaran pada saat itu.

Karakteristik media yang dipakai dalam kegiatan belajar mengajar dibedakan menjadi media pembelajaran berbasis visual, media pembelajaran berbasis audio, media pembelajaran berbasis audio visual dan media pembelajaran berbasis komputer. Media pembelajaran bebasis komputer dilengkapi dengan software-software yang memudahkan dalam pembelajaran. Salah satu contoh media digital adalah software cartoon story maker. Cartoon story maker adalah software offline yang dapat digunakan untuk membuat kartun 2 (dua) dimensi. Software ini sudah dilengkapi dengan berbagai karakter dengan ekspresi wajah yang berbedabeda serta latar cerita yang beragam. Selain itu, siswa dapat mengunggah gambar mereka sendiri untuk dijadikan karakter atau latar cerita. Cartoon story maker dapat digunakan untuk menggambarkan percakapan dan dialog, cerita dapat mencakup jumlah frame yang tidak terbatas, untuk menambahkan suara sebagai pelengkap gambar dan teks 
pada cerita dan melihat frame demi frame, fitur dari software ini antara lain:

- Karakter dan latar belakang perpustakaan

- Mengimpor gambar sendiri

- Teks gelembung dan kotak informasi

- Akses tombol panel

- Impor suara rekaman

- Dibangun perekam untuk menambah rekaman suara sendiri

- Unlimited jumlah frame

- Copy dan paste frame

- Pratinjau

- Print fungsi

- Cerita yang disimpan dapat dibuka dan diedit

- Copy dan paste dari dokumen teks lainya

Aplikasi Cartoon story maker menarik untuk pengajaran karena sangat mudah digunakan dan menyediakan cara yang mudah untuk memasukkan teks. Cartoon story maker dapat dibuat dan dilihat kapan saja dan di mana saja oleh pengguna.

Mempertimbangkan manfaat dari penggunaan software cartoon story maker dalam pembelajaran maka para guru dan kepala sekolah bersama dengan program kemitraan masyarakat (PKM) memandang perlu diadakannya kegiatan pelatihan di sekolah tersebut. Kegiatan ini dimaksudkan agar guru dapat menggunakan cartoon story maker untuk meningkatkan kualitas pembelajaran dan kreativitas guru dalam mengajar sehingga dapat terciptanya pembelajaran aktif dan interaktif.

\section{METODE PELAKSANAAN Metode Pelaksanaan}

Metode pelaksanaan PKM pada program pelatihan guru dapat menggunakan cartoon story maker sebagai media pembelajaran digital ini dibagi menjadi empat tahapan, yaitu:

\section{Tahap pendahuluan}

Dalam tahap ini pengabdi mempersiapkan surat izin dengan pihak terkait, mempersiapkan tempat pelatihan, serta mempersiapkan alat dan bahan.

\section{Tahap sosialisasi dan audiensi Sosialisasi mengenai} pelatihan penggunaan media digital yaitu cartoon story maker dilakukan dengan cara mengumpulkan setiap guru yang berada di lingkungan Sekolah Dasar Swasta Islam Terpadu Uli Arga Kecamatan Patumbak Kabupaten Deli Serdang. Di awal pertemuan, peserta diberi penjelasan mengenai apa manfaat penggunaan mdia digital cartoon story maker dalam pembelajaran sehingga penggunaan media ini dapat menciptakan suasana yang aktif dan interaktif.

III. Tahap pelatihan penggunaaan cartoon story maker sebagai media pembelajaran

Tahapan ini berupa kegiatan pelatihan penggunan cartoon story maker kepada guru-guru SD Swasta Islam Terpadu Uli Arga.Terlebih dahulu peserta mendownload software cartoon story maker di laptop masing-masing peserta. Selanjutkan peserta terlebih dahulu mendengarkan dan menyimak langkah-langkah dalam menggunakan cartoon story maker lalu peserta akan dibimbing untuk mengembangkan kreatifitasnya dengan menggunakan cartoon story maker. Cartoon story maker adalah software offline yang dapat digunakan untuk membuat kartun 
2(dua) dimensi. Software ini sudah dilengkapi dengan berbagai karakter dengan ekspresi wajah yang berbedabeda serta latar cerita yang beragam. Selain itu, peserta dapat mengunggah gambar mereka sendiri untuk dijadikan karakter atau latar cerita. Cartoon story maker dapat digunakan untuk menggambarkan percakapan dan dialog, cerita dapat mencakup jumlah frame yang tidak terbatas, untuk menambahkan suara sebagai pelengkap gambar dan teks pada cerita dan melihat frame demi frame, fitur dari software tersebut.

\section{Tahap Evaluasi Akhir}

Pada tahapan ini, guru diberi kesempatan untuk seputar penggunaan cartoon story maker serta kesan saat menggunakan software tersebut. Tahapan ini bertujuan untuk memberi kesempatan kepada guru untuk mengekspresikan keingintahuan mereka dalam penggunaan media digital terutaman cartoon story maker dan mengevaluasi hasil kegiatan pengabdian.

\section{HASIL DAN PEMBAHASAN}

Pemaparan tentang penggunaan media digital yaitu cartoon story maker di Sekolah Dasar Swasta Islam Terpadu Uli Arga yang berlokasi di Jalan Mambang Diawan V Patumbak Sigara-gara Kecamatan Patumbak Kabupaten Deli Serdang membuat guru- guru antusias dalam bertanya. Mereka ingin mengetahui lebih lanjut tentang penggunaan media tersebut. Pada saat mempraktekkan penggunaan media tesebut, guruguru menjadi sangat aktif dan kreatif dalam mengembangkan materi pembelajarannya. Seperti yang diketahui, media komik kartun memiliki 5 kelebihan yaitu : 1) dapat memotivasi, 2) visual menarik, 3) permanen, 4) perantara, dan 5) populer sedangkan media gambar mempunyai keunggulan mudah digunakan, mudah dimengerti, mudah dibuat, dan lebih mudah dalam memberi penjelasan daripada menggunakan media verbal. Media gambar juga memiliki kelemahan yaitu : 1) tidak cukup besar ukurannya, 2) gambar adalah berdimensi dua, 3) gambar bagaimanapun indahnya tetap tidak memperlihatkan gerak seperti halnya gambar hidup. Cartoon story maker (komik bergambar) merupakan software offline yang digunakan untuk membuat percakapan atau dialog dengan menggunakan gelembung percakapan, deskripsi gambar serta latar belakang yang dapat disesuaikan dengan tema atau konteks percakapan. Beberapa fitur yang tersedia adalah karakter orang, pengaturan dan dialog gelembung. Lokasi dan karakter dapat digantikan dari file apa pun dan materi yang tidak diunggah serta ada dua mode dialog dialog tertulis dan dialog berbasis suara. Keunggulan cartoon story maker yaitu memilki karakter dan latar belakang yang bervariasi serta dapat dibentuk dalam bentuk rekaman. Media ini juga memiliki banyak ekspresi karakter yang unik dan menarik sehingga cerita akan mudah dimengerti sehingga guru dapat dengan mudah menyampaikan materi pembelajarannya dan media pembelajaran ini memuat gambar dan cerita yang menarik sehingga dapat membuat siswa tertarik dalam pembelajaran.

\section{KESIMPULAN}

Banyak media yang dapat digunakan dalam pengajaran bahasa 
Inggris. Media yang digunakan dalam disesuaikan dengan perkembangan zaman dan anak. Salah satu contohnya adalah cartoon story maker. Software offline ini dapat digunakan untuk menggambarkan percakapan dan dialog, cerita, dapat mencakup jumlah frame yang tidak terbatas, juga dapat menambahkan suara sebagai pelengkap gambar dan teks pada cerita dan melihat frame demi frame. Software ini sudah dilengkapi dengan berbagai karakter dengan ekspresi wajah yang berbeda-beda serta latar cerita yang beragam. Selain itu, peserta dapat mengunggah gambar mereka sendiri untuk dijadikan karakter atau latar cerita. Dengan menggunakan software ini, siswa dapat menjadi lebih aktif dan kreatif.

\section{REFERENSI}

Anshar, dkk. 2017. Tingkat Aksesibilitas dan Pemanfaatan Media Baru Dalam Proses Pembelajaran dan Interaksi Sosial di Kalangan Pelajar Siswa Menengah Pertama. Jurnal Komunikasi KAREBA. Vol. 6 No. 1 Januari-Juni. Universitas Hasanuddin

Dewi, Mas Ayu Rosiana. 2019. Pengembangan

Pembelajaran Komik Fiska berbasis Cartoon Story Maker Pada Materi Kalor Untuk Tingkat SMP/MTS Kelas VII. Skripsi. UIN Raden Intan Lampung

Firdaus, Thoha. 2018. Pemanfaatan Media Berbasis Teknologi Dalam Pembelajaran.
Artikel:

Media

Pembelajaran STKIP Nurul Huda. UPI. Bandung

Nursamsu, dan Kusnafizal, Teuku. 2017. Pemanfaatan Media Pembelajaran ICT Sebagai Kegiatan Pembelajaran Siswa di SMP Negeri Aceh Tamiang. Jurnal IPA dan Pembelajaran IPA (JIPI), 1(2), 165-170. Desember. PISSN:2614-0500.Unsyiah

Riwanto, Mawan Akhir, dan Wulandari, Mey Prihandani. 2018. Efektivitas Penggunaan Media Komik Digital (Cartoon Story Maker) dalam Pembelajaran Tema Selalu Hemat Berenergi, Jurnal Pancar Vol. 2 No. 1 April, Cilacap.

Sukiman. (2012). Pengembangan Media Pembelajaran. Yogyakarta: Pedagogia

Zufria, Ilka. 2016. Pemanfaatan Media Digital (E-learning) dalam Memaksimalkan Proses Belajar Mengajar di Perguruan Tinggi. Jurnal Pendidikan Islam dan Teknologi Pendidikan. NIZHAMIYAH, Vol. VI, No. 1, Januari-Juni.ISSN : 2086 - 4205. UIN Sumatera Utara 